\title{
Center the Relationship between Self-Leadership Behaviors of Sports-Sports Training Specialists and Job Satisfaction Levels (An Example from Eastern Anatolia Region)
}

\author{
Muhammed Bahadır Sandıkçı (Corresponding author) \\ Faculty of Sports Sciences, Munzur University, Tunceli, Turkey \\ E-mail: mbsandikci@munzur.edu.tr
}

Metin Y1ld1z

Ministry of Youth and Sports Provicial Directorate, Elazığ, Turkey

E-mail: metinyildiz.2323@gmail.com

\author{
Abdurrahman Kirtepe \\ Faculty of Sports Sciences, Frrat University, Elazığ, Turkey \\ E-mail: akirtepe@firat.edu.tr
}

Received: November 5, $2021 \quad$ Accepted: December 7, 2021

Published: December 31, 2021

doi:10.5296/jei.v7i3.19183 URL: https://doi.org/10.5296/jei.v7i3.19183

A part of this study was submitted as an oral presentation at the $10^{\text {th }}$ International Congress on Social Sciences, Humanities and Educational Sciences.

\begin{abstract}
This study aims to determine the relationship between self-leadership behaviors and job satisfaction levels of Sports-Sports Training Specialists working in Provincial Directorates of Youth and Sports. The research population consists of 230 Sports-Sports Training Specialists working in the Provincial Directorates of Youth and Sports in the Eastern Anatolia Region.
\end{abstract}




\section{MInstitute Macroth $_{\text {Int }}$}

"Personal Information Form", "Self-Leadership Questionnaire-SLQ" and "Job Satisfaction Scale" were used for data collection. $72.2 \%$ of the participants are male, $73.4 \%$ have an undergraduate degree and $64.6 \%$ are working in their institution on a contractual basis. There is a significant difference in favor of women between gender and the self-talk sub-dimension of the self-leadership scale. There was a significant difference between the working positions and the total score of the self-leadership scale and the sub-dimension of self-cueing in favor of permanent employees. There was a statistically significant difference between the job satisfaction scale and the sports training specialists having poor economic status. No positive relationship was found between self-leadership and job satisfaction. It has been concluded that female sports-sports training specialists are more focused on self-talk than males and this has an effect on self-leadership levels, but gender does not affect their job satisfaction levels. Permanent staff experts motivate themselves better and have a better sense of self-leadership than contracted experts. It has been determined that compared to their senior colleagues, newcomers to the profession are in an effort to reveal their self-leadership behaviors more in order to prove themselves in their institutions and to be successful.

Keywords: Sports-sports training specialist, Self-leadership, Job satisfaction

\section{Introduction}

Today, leadership includes impressive and guiding abilities in order to lead people to their goals in a conscious and orderly manner in line with certain goals. A good and successful leader is not only the person who makes her/his members successful professionally, but also the person who gives confidence, motivates and persuades the members (Önen \& Kanayran, 2015).

Self-leadership is a process in which individuals control their own behaviors and direct themselves through self-influence with certain cognitive behavioral strategies (Manz, 1986). The concept of self-leadership first emerged in the mid-1980s with the extension of the concept of self-management, influenced by the leadership substitutions idea of Kerr and Jermier (1978) (Neck \& Houghton, 2006). Self-leadership draws attention to the ways in which a job should be done, as well as what should be done and why. Self-leadership is an alternative perspective to traditional structures in which the power of control and influence rests with appointed leaders (Pearce \& Manz, 2005). People motivate themselves sufficiently to do work in self-leadership (Manz \& Neck, 2004). Self-leadership derives from the theories of self-control, social learning and self-management. From the perspective of self-influence, self-leadership has three stages (James, 2009). These stages are self-control, self-management and self-leadership.

"İş tatmini" in Turkish is explained by the translation of the term "Job satisfaction" in English and includes the satisfaction of the employees towards work. Accordingly, job satisfaction is an evaluation made by the employee by considering all the factors related to her/his job. The attitude and behaviors of the employee towards the job are determined with job satisfaction. When the studies in the literature are examined, it is observed that job satisfaction is used as "work satisfaction" (Özkalp \& Kırel, 2016). Job satisfaction, with its most general definition, is explained as positive feelings or satisfaction of employees towards work. Employees' 
satisfaction with their attitudes towards work can occur at many different levels. For example, an employee may be satisfied with the responsibilities assigned while another employee may express the dissatisfaction with these responsibilities (Can, Azizoğlu, \& Miski, 2015).

Some authors consider job satisfaction as a reaction of the employee to the job. If the reaction of the employees towards the work is positive, and the job satisfaction is negative, dissatisfaction can be experienced (Eğinli, 2009; Bayrak Kök, 2006).

Individuals enter into an emotional and cognitive evaluation of their psychological state, both temporarily and permanently for a moment, and they give feedback on the job with this self-evaluation. This feedback is defined as job satisfaction (Aşan \& Erenler, 2008).

Job satisfaction is an indispensable element of working life. Depending on the personality of the employee and the workplace, people are in a constant evaluation in their psychological world. This evaluation is to interpret various events in working life, to make comparisons and to determine the attitudes towards certain behaviors with this comparison (Eren, 2017).

First of all, job satisfaction is the state of the employee to feel happy and peaceful. The term that meets this emotional state is called satisfaction. The high level of job satisfaction of the employee has a decisive and very important position on job satisfaction (Karakuş, 2011). The reason why the issue of job satisfaction has gained a lot of importance in recent years is the increasing number of problems arising from the human factor in organizations and looking for the way of eliminating these problems. Contemporary management approach reflects the evaluation of the contribution of the employee's success to the organization, motivating the employees to put all their efforts and providing the highest material and moral satisfaction from the work done by the employee (Şahal, 2005). In addition, job satisfaction can be accepted as an indicator of the welfare of the employees (Öztekin, 2008).

In this context, the aim of the study is to determine the relationship between self-leadership behaviors and job satisfaction levels of Sports-Sports Training Specialists working in Provincial Directorates of Youth and Sports according to different variables.

\section{Method}

\subsection{Research Group}

The research population is composed of 230 Sports-Sports Training Specialists who work in the Eastern Anatolia Region Provincial Directorates of Youth and Sports (Ağr1: 7, Ardahan: 9, Bitlis: 10, Bingöl: 12, Elazı̆̆: 41, Erzincan: 14, Erzurum: 31, Hakkari: 8, Iğdır: 5, Kars: 8, Malatya: 30, Muş: 13, Tunceli: 16, Van: 21). In the study, 158 out of 230 sports training specialists were included in the sampling by convenience sampling method.

\subsection{Research Design}

The model of this research is the relational survey model being one of the quantitative research methods. 


\subsection{Data Collection Tools}

The researcher reached the participants through online applications after obtaining the necessary ethics committee permissions to perform the questionnaires. Afterwards, the questionnaire was explained to the sports-sports training specialists to whom the questionnaire would be administered, and they were helped to answer the questions in a healthy way. The questionnaire form consists of two parts. These are;

Personal Information Form: The personal information form consists of the questions prepared by the researchers in order to determine the gender, marital status, educational status, province of worked, position, working year, economic income level of the participants.

Self-Leadership Questionnaire-SLQ: Self-Leadership Questionnaire-SLQ was developed by Anderson and Prussia (1997) and the Revised Self-Leadership Questionnaire-RSLQ was later confirmed by Houghton and Neck (2002), adapted into Turkish by Tabak et al. (2013) and its reliability and validity studies were carried out. Since the generally accepted standard alpha value is .70 and above, the reliability values of the internal consistency coefficients in the dimensions of the scale are at an acceptable level. The scale consists of 29 items and a 5-point Likert type that indicates the participation frequency in the items. It is composed of 3 dimensions namely Behavior Focused Strategies, Natural Reward Strategies and Constructive Thought Strategies and 8 sub-dimensions of Visualizing Successful Performance by Setting Targets (VSPST) $(1,8,16,17,23,24,28)$, Self-talk (ST) $(2,9,18)$, Self-reward (SR) $(3,19,10)$, Evaluating Beliefs and Assumptions (EBA) $(4,11,20,25)$, Self-punishment (SP) $(5,12,21,26)$, Self-observation (SO) $(6,13,22,27)$, Focusing Thoughts on Natural Rewards (FTNR) $(14,29)$ and Self-cueing (SC) $(7,15)$. Due to the problems arising from the negative effects of the items that make up the self-punishment strategy of the scale, four items that make up this dimension were included in the evaluations by being reverse coded. As a result of the reliability and validity study conducted by the researchers, it has been stated that the scale is a reliable and valid scale with acceptable values (Tabak et al., 2013).

Job Satisfaction Scale: Akkan's (2008) “Job Satisfaction” scale was used in the preparation of this scale. In the study in this part, 10 questions were asked in order to measure the job satisfaction levels of the participants. Participants filled out the scale by ticking a single option for each question in the 5-point Likert type scale with "strongly disagree, disagree, undecided, agree, strongly agree". The grading is as follows; I strongly disagree $=1$, I do not agree $=2$, I am undecided $=3$, I agree $=4$, I strongly agree $=5$.

\subsection{Statistical Analysis}

The data analysis was carried out with the SPSS 25 package program. Frequency and percentage values were presented for qualitative variables, arithmetic mean and standard deviation values were presented for quantitative variables. Independent sample t-test was used for comparisons between two-category qualitative and quantitative variables. One-way Anova was used for comparisons between qualitative variables and quantitative variables containing more than two categories. In case there was a significant difference in the one-way Anova result, the categories were compared in pairs by using the Tukey's test being one of 
the post-hoc methods. Pearson correlation was used for comparisons between two quantitative variables. If the $\mathrm{p}$ value was found to be less than 0.05 in the research, it was considered significant.

\section{Results}

Table 1. Demographic information of the participants

\begin{tabular}{|l|l|l|l|}
\hline \multirow{4}{*}{ Gender } & & $\mathrm{n}$ & $\%$ \\
\hline \multirow{4}{*}{ Educational Status } & Male & 114 & 72.2 \\
\cline { 2 - 4 } & Female & 44 & 27.8 \\
\hline \multirow{4}{*}{ Working Position } & PhD & 20 & 1.3 \\
\cline { 2 - 4 } & Bachelor's degree & 116 & 73.4 \\
\cline { 2 - 4 } & Master's degree & 40 & 25.3 \\
\hline \multirow{5}{*}{ Working Year } & Permanent & 56 & 35.4 \\
\cline { 2 - 4 } & Contracted & 102 & 64.6 \\
\hline \multirow{5}{*}{ Income Level } & $1-5$ Years & 95 & 60.1 \\
\cline { 2 - 4 } & 6-10 Years & 48 & 30.4 \\
\cline { 2 - 4 } & 11 Years and more & 15 & 9.5 \\
\hline & Bad & 43 & 27.2 \\
\cline { 2 - 4 } & Middle & 80 & 50.6 \\
\cline { 2 - 4 } & Good & 35 & 22.2 \\
\hline
\end{tabular}

According to the data in Table 1, regarding the gender variable of the participants, there are 114 male participants (72.2\%) and 44 female participants $(27.8 \%), 116$ people $(73.4 \%)$ have a bachelor's degree, 40 people have a master's degree $(25.3 \%)$ and 2 people $(1.3 \%)$ have a $\mathrm{PhD}$ degree with the lowest participation regarding educational status variable; when the working position variable of the individuals is examined, $102(64.6 \%)$ of the participants work in contracted positions and $56(35.4 \%)$ people work in permanent positions. Looking at the income level variable of the participants, $80(50.6 \%)$ people are in the middle-income group, $43(27.2 \%)$ people are in the bad income group and $35(22.2 \%)$ people are in the high-income group. Considering the variable of the province where individuals work, the highest participation rate is in Elazığ province with 36 people $(22.8 \%)$, and the province with the lowest participation is Iğdır and A $\breve{g r}$ with $3(1.9 \%)$ people. 
Table 2. Comparisons between gender categories in terms of scale scores

\begin{tabular}{|l|l|l|l|l|}
\hline & Male & Female & $\mathrm{t}$ & $\mathrm{p}$ \\
\hline & $\overline{\mathrm{x}} \pm \mathrm{SS}$ & $\overline{\mathrm{x}} \pm \mathrm{SS}$ & & \\
\hline VSPST & $4.2 \pm 0.62$ & $4.12 \pm 0.76$ & .621 & .537 \\
\hline ST & $3.73 \pm 0.74$ & $4.02 \pm 0.77$ & -2.132 & .035 \\
\hline SR & $3.95 \pm 0.71$ & $3.77 \pm 0.67$ & 1.495 & .137 \\
\hline EBA & $4.22 \pm 0.57$ & $4.08 \pm 0.73$ & 1.145 & .256 \\
\hline SP & $3.39 \pm 0.92$ & $3.4 \pm 0.8$ & -.069 & .945 \\
\hline SO & $4.25 \pm 0.6$ & $4.2 \pm 0.74$ & .379 & .705 \\
\hline FTNR & $4.23 \pm 0.68$ & $4.3 \pm 0.64$ & -.568 & .571 \\
\hline SC & $4.01 \pm 0.84$ & $4.03 \pm 0.9$ & -.137 & .891 \\
\hline Self-leadership & $3.99 \pm 0.49$ & $3.96 \pm 0.51$ & .333 & .740 \\
\hline Job satisfaction & $3.31 \pm 0.83$ & $3.09 \pm 0.72$ & 1.536 & .126 \\
\hline
\end{tabular}

According to Table 2, while there was a significant difference in favor of women $(p<0.05)$ between gender of Sports-Sports Training Specialists and the self-talk (ST) sub-dimension of the self-leadership scale, no statistically significant difference was found between other sub-dimensions and job satisfaction scale and gender $(\mathrm{p}>0.05)$.

Table 3. Comparisons between work position categories in terms of scale scores

\begin{tabular}{|l|l|l|l|l|}
\hline & Permanent & Contracted & $\mathrm{t}$ & $\mathrm{p}$ \\
\hline & $\overline{\mathrm{x}} \pm \mathrm{SS}$ & $\overline{\mathrm{x}} \pm \mathrm{SS}$ & & \\
\hline VSPST & $4.3 \pm 0.57$ & $4.11 \pm 0.7$ & 1.861 & .065 \\
\hline ST & $3.9 \pm 0.73$ & $3.76 \pm 0.77$ & 1.162 & .247 \\
\hline SR & $3.99 \pm 0.63$ & $3.85 \pm 0.74$ & 1.190 & .236 \\
\hline EBA & $4.29 \pm 0.58$ & $4.12 \pm 0.63$ & 1.598 & .112 \\
\hline SP & $3.51 \pm 0.88$ & $3.33 \pm 0.89$ & 1.193 & .235 \\
\hline SO & $4.29 \pm 0.56$ & $4.21 \pm 0.68$ & .789 & .431 \\
\hline FTNR & $4.31 \pm 0.55$ & $4.21 \pm 0.72$ & .990 & .324 \\
\hline SC & $4.24 \pm 0.63$ & $3.9 \pm 0.94$ & 2.741 & .007 \\
\hline Self-leadership & $4.09 \pm 0.46$ & $3.93 \pm 0.5$ & 2.070 & .040 \\
\hline Job satisfaction & $3.41 \pm 0.74$ & $3.16 \pm 0.82$ & 1.821 & .071 \\
\hline
\end{tabular}


According to Table 3, there was a significant difference in favor of permanent employees between the working positions of Sports-Sports training specialists, the total score of the self-leadership scale and the sub-dimension of self-cueing $(\mathrm{p}<0.05)$. There was no statistically significant difference between the total score of the job satisfaction scale and the other sub-dimensions of the self-leadership scale and the working positions of sports-sports training specialists $(\mathrm{p}>0.05)$.

Table 4. Comparisons between working year categories in terms of scale scores

\begin{tabular}{|l|l|l|l|l|l|}
\hline & $1-5$ Years & $6-10$ Years & 11 Years and more & $\mathrm{f}$ & $\mathrm{p}$ \\
\hline & $\overline{\mathrm{x}} \pm \mathrm{SS}$ & $\overline{\mathrm{x}} \pm \mathrm{SS}$ & $\overline{\mathrm{x}} \pm \mathrm{SS}$ & & \\
\hline VSPST & $4.1 \pm 0.71$ & $4.27 \pm 0.6$ & $4.34 \pm 0.49$ & 1.564 & 0.213 \\
\hline ST & $3.71 \pm 0.8$ & $4.01 \pm 0.69$ & $3.84 \pm 0.64$ & 2.585 & 0.079 \\
\hline SR & $3.82 \pm 0.73$ & $4.06 \pm 0.64$ & $3.84 \pm 0.63$ & 1.911 & 0.151 \\
\hline EBA & $4.11 \pm 0.64$ & $4.31 \pm 0.57$ & $4.23 \pm 0.6$ & 1.744 & 0.178 \\
\hline SP & $3.32 \pm 0.88$ & $3.54 \pm 0.95$ & $3.42 \pm 0.74$ & 1.017 & 0.364 \\
\hline SO & $4.18 \pm 0.71$ & $4.3 \pm 0.53$ & $4.37 \pm 0.52$ & 0.906 & 0.406 \\
\hline FTNR & $4.19 \pm 0.73$ & $4.36 \pm 0.56$ & $4.2 \pm 0.49$ & 1.075 & 0.344 \\
\hline SC & $3.89 \pm 0.95$ & $4.24 \pm 0.61$ & $4.13 \pm 0.81$ & 2.885 & 0.059 \\
\hline Self-leadership & $3.91 \pm 0.5$ & $4.12 \pm 0.5$ & $4.05 \pm 0.34$ & 3.083 & 0.049 \\
\hline Job satisfaction & $3.28 \pm 0.78$ & $3.11 \pm 0.83$ & $3.5 \pm 0.82$ & 1.599 & 0.205 \\
\hline
\end{tabular}

According to Table 4, it was determined that there was a statistically significant difference between the working years in the profession of Sports-Sports Training specialists and the total score of the self-leadership scale with a higher average of those working for 1-5 years ( $p$ $<0.05)$. There was no statistically significant difference between the job satisfaction scale and self-leadership sub-dimensions and the working years of sports-sports training specialists $(\mathrm{p}>0.05)$. 


\section{Macrothink}

Table 5. Comparisons between economic status categories in terms of scale scores

\begin{tabular}{|l|l|l|l|l|l|}
\hline & Bad & Middle & Good & $\mathrm{f}$ & $\mathrm{p}$ \\
\hline & $\overline{\mathrm{x}} \pm \mathrm{SS}$ & $\overline{\mathrm{x}} \pm \mathrm{SS}$ & $\overline{\mathrm{x}} \pm \mathrm{SS}$ & & \\
\hline VSPST & $4.06 \pm 0.74$ & $4.25 \pm 0.64$ & $4.13 \pm 0.61$ & 1.285 & 0.280 \\
\hline ST & $3.82 \pm 0.73$ & $3.82 \pm 0.82$ & $3.78 \pm 0.67$ & 0.033 & 0.967 \\
\hline SR & $3.84 \pm 0.72$ & $3.93 \pm 0.69$ & $3.9 \pm 0.7$ & 0.240 & 0.787 \\
\hline EBA & $4.12 \pm 0.71$ & $4.27 \pm 0.56$ & $4.05 \pm 0.59$ & 1.916 & 0.151 \\
\hline SP & $3.41 \pm 0.8$ & $3.33 \pm 0.98$ & $3.53 \pm 0.75$ & 0.606 & 0.547 \\
\hline SO & $4.09 \pm 0.72$ & $4.34 \pm 0.6$ & $4.17 \pm 0.61$ & 2.347 & 0.099 \\
\hline FTNR & $4.12 \pm 0.65$ & $4.34 \pm 0.69$ & $4.2 \pm 0.62$ & 1.662 & 0.193 \\
\hline SC & $4.05 \pm 0.86$ & $4.03 \pm 0.86$ & $3.97 \pm 0.87$ & 0.077 & 0.926 \\
\hline Self-leadership & $3.92 \pm 0.52$ & $4.03 \pm 0.49$ & $3.96 \pm 0.46$ & 0.745 & 0.477 \\
\hline Job satisfaction & $2.78 \pm 0.83$ & $3.37 \pm 0.73$ & $3.56 \pm 0.68$ & 12.450 & $<0.001 *$ \\
\hline
\end{tabular}

According to Table 5, no statistically significant difference was found between the economic status of sports-sports training specialists and the sub-dimensions of the self-leadership scale $(p>0.05)$. There was a statistically significant difference between the job satisfaction scale and the sports training specialists having poor economic status $(\mathrm{p}<0.05)$. 
Table 6. Analysis of the existence of a relationship between the scale and sub-dimension

\begin{tabular}{|c|c|c|c|c|c|c|c|c|c|c|c|}
\hline & & VSPST & ST & SR & EBA & SP & SO & FTNR & $\mathrm{SC}$ & Self-leadership & Job satisfaction \\
\hline \multirow{2}{*}{ VSPST } & $\mathrm{r}$ & 1 & $0.438^{* *}$ & $.568^{* *}$ & $.800^{* *}$ & 0.05 & $.815^{* *}$ & $.725^{* *}$ & $.362^{* *}$ & $.865^{* *}$ & $0.192^{*}$ \\
\hline & $\mathrm{p}$ & & $<0.001$ & $<0.001$ & $<0.001$ & 0.537 & $<0.001$ & $<0.001$ & $<0.001$ & $<0.001$ & 0.015 \\
\hline \multirow{2}{*}{ ST } & $\mathrm{r}$ & & 1 & $.449^{* *}$ & $.423^{* *}$ & $.245^{* *}$ & $.418^{* *}$ & $.479^{* *}$ & $.331^{* *}$ & $.663^{* *}$ & 0.035 \\
\hline & $\mathrm{p}$ & & & $<0.001$ & $<0.001$ & 0.002 & $<0.001$ & $<0.001$ & $<0.001$ & $<0.001$ & 0.666 \\
\hline \multirow{2}{*}{ SR } & $\mathrm{r}$ & & & 1 & $.605^{* *}$ & 0.049 & $.442^{* *}$ & $.513^{* *}$ & $.487^{* *}$ & $.722^{* *}$ & 0.108 \\
\hline & $\mathrm{p}$ & & & & $<0.001$ & 0.543 & $<0.001$ & $<0.001$ & $<0.001$ & $<0.001$ & 0.176 \\
\hline \multirow{2}{*}{ EBA } & $\mathrm{r}$ & & & & 1 & 0.094 & $.751^{* *}$ & $.624^{* *}$ & $.340^{* *}$ & $.810^{* *}$ & 0.09 \\
\hline & $\mathrm{p}$ & & & & & 0.242 & $<0.001$ & $<0.001$ & $<0.001$ & $<0.001$ & 0.261 \\
\hline \multirow{2}{*}{ SP } & $\mathrm{r}$ & & & & & 1 & 0.069 & 0.04 & 0.085 & $.357^{* *}$ & 0.014 \\
\hline & $\mathrm{p}$ & & & & & & 0.386 & 0.619 & 0.291 & $<0.001$ & 0.86 \\
\hline \multirow{2}{*}{ SO } & $\mathrm{r}$ & & & & & & 1 & $.739^{* *}$ & $.364^{* *}$ & $.804^{* *}$ & 0.149 \\
\hline & $\mathrm{p}$ & & & & & & & $<0.001$ & $<0.001$ & $<0.001$ & 0.062 \\
\hline \multirow{2}{*}{ FTNR } & $\mathrm{r}$ & & & & & & & 1 & $.416^{* *}$ & $.772^{* *}$ & 0.129 \\
\hline & $\mathrm{p}$ & & & & & & & & $<0.001$ & $<0.001$ & 0.107 \\
\hline \multirow{2}{*}{$\mathrm{SC}$} & $\mathrm{r}$ & & & & & & & & 1 & $.560^{* *}$ & $0.204^{*}$ \\
\hline & $\mathrm{p}$ & & & & & & & & & $<0.001$ & 0.01 \\
\hline \multirow{2}{*}{ Self-leadership } & $\mathrm{r}$ & & & & & & & & & 1 & $.179^{*}$ \\
\hline & $\mathrm{p}$ & & & & & & & & & & 0.024 \\
\hline \multirow{2}{*}{ Job satisfaction } & $\mathrm{r}$ & & & & & & & & & & 1 \\
\hline & $\mathrm{p}$ & & & & & & & & & & \\
\hline
\end{tabular}

Note. $* \mathrm{p}<0.05 ; * * \mathrm{p}<0.1$.

According to Table 6, concerning the self-leadership scale of sports-sports training specialists, there was a low level of positive relationship between Visualizing Successful Performance by Setting Targets sub-dimension and Self-talk sub-dimension, moderate level relationship with Self-reward and no relationship was found with the sub-dimension of Self-punishment. There was a high positive correlation with the sub-dimension of Self-observation and Focusing Thoughts on Natural Rewards and Evaluating Beliefs and Assumptions sub-dimension while a low-level positive correlation was observed with the Self-cueing sub-dimension. While a high level of correlation was observed between the Visualizing Successful Performance by Setting Targets sub-dimension and the total self-leadership scale, no significant relation was ascertained with the job satisfaction scale. A moderately positive relationship was found between the sub-dimension of Self-talk and Self-reward, Evaluating Beliefs and Assumptions, Self-observation and Focusing Thoughts on Natural Rewards sub-dimension; on the other hand, there was a weakly positive relationship between the sub-dimensions of 
Self-punishment and Self-cueing. A highly positive relationship was not found between the self-talk sub-dimension and the self-leadership scale, and a positive relationship was not found with the job satisfaction scale.

While a highly positive correlation was ascertained between the sub-dimension of self-reward, Evaluating Beliefs and Assumptions sub-dimension and self-leadership scale, a moderate correlation was found between the sub-dimension of Self-observation, Focusing Thoughts on Natural Rewards and Self-cueing. There was no positive relationship between the sub-dimensions of self-reward, self-punishment and job satisfaction scale.

There was a high level of correlation between the Evaluating Beliefs and Assumptions sub-dimension and Self-observation and Focusing Thoughts on Natural Rewards sub-dimensions and the self-leadership scale. However, no relationship was observed between self-punishment and job satisfaction. A weak correlation was found between the sub-dimension of Evaluating Beliefs and Assumptions and Self-cueing.

No positive correlation was observed between the sub-dimension of Self-punishment and Self-observation, Focusing Thoughts on Natural Rewards, Self-cueing and job satisfaction scale. A weakly positive relationship was determined between the self-punishment sub-dimension and the self-leadership scale.

A high level of positive correlation was found between the sub-dimension of Self-observation and Focusing Thoughts on Natural Rewards and self-leadership. There was a weak correlation between Self-observation sub-dimension and Self-cueing sub-dimension, but no positive correlation was found with job satisfaction.

Moderately positive relationship was established between the sub-dimensions of Focusing Thoughts on Natural Reward and Self-cueing and a highly positive relationship was found with self-leadership scale while no positive correlation was ascertained between job satisfaction and Focusing Thoughts on Natural Rewards.

There was a moderately positive relationship between elf-cueing sub-dimension and self-leadership while it was a low level of positive correlation with job satisfaction. No positive correlation was observed between self-leadership and job satisfaction.

\section{Discussion}

It has been observed in this study that women have a higher mean score than men between the genders of the participants and the self-talk sub-dimension of the self-leadership scale. In the study conducted by Aril (2011) on primary school teachers, it was concluded that female teachers use self-reward and self-talk strategies more than male teachers. In the study conducted by Yavuz and Ayhan (2019), it was determined that the level of using the dimension of self-talk being among the self-leadership dimensions is higher in female employees compared to male employees. In a study conducted by Ergöz (2018) on employees in a hospital in Istanbul province, it was concluded that there was no significant difference between the self-leadership levels of the employees and their gender. The studies performed gave similar results with our research. It can be said that women are more focused on 
self-talk than men and this has an effect on their self-leadership levels. In the researches looking at the relationship between job satisfaction and gender, no significant difference was reached between gender and job satisfaction (Gürkan et al., 2017; Sarıbay \& Sarıbay, 2016; Tor and Esengün, 2011; Gholamtoobani, 2018). It was stated in the researches yielding opposite results with our study that satisfaction levels of women were lower than men (Mercanlıoglu, 2012) while some researches indicated that satisfaction levels of women were higher than men (Güvel, 2019; Sina, 2019; Karakuzu, 2019; Tunacan \& Çetin, 2009). It can be stated that the gender status of the participants does not affect their job satisfaction levels since they have equal personal rights under the same conditions.

A significant difference was determined in favor of permanent employees between the working positions of Sports-Sports training specialists, the total score of the self-leadership scale and the sub-dimension of self-cueing. It has been observed that permanent specialists have a higher mean score than contracted specialists in the self-cueing and self-leadership scale. Due to the existing personal rights, permanent specialists may perceive objects and people as helping to focus attention, and when they see them, they may think that they motivate themselves better for their work and lead to a better sense of leadership.

It has been determined that between the working years of Sports-Sports training specialists in the profession and the total score of the self-leadership scale, those who work between 1-5 years have a higher average than those who work longer. In the study conducted by Arl (2011) on teachers, it was stated that the tendency of exhibiting self-leadership behaviors decreased as the working hours and ages of the teachers included in the research increased. In this respect, the research gave similar results with our study. We can say that specialists who are new to the profession are in an effort to prove themselves in their institutions and to reveal their self-leadership behaviors more in order to be successful compared to their senior colleagues.

In the study conducted by Sarıbay and Sarıby (2016), it is stated that the employees working in local governments do not differ regarding their job satisfaction levels according to their length of service, and in the study conducted by Gholamtoobani (2018), no statistically significant difference was found in terms of working hours and job satisfaction scores of the participants. The researches yielded parallel results with our study. In the study conducted by Gürkan et al. (2017) examining the total working period of the employees, it was determined that those working between 1 and 5 years had higher levels of internal satisfaction, and those who served 6-10 years in the profession had higher external satisfaction levels while it was also established that the internal and external satisfaction levels of those working for 10 years or more show a decreasing trend, the expectations of the employees regarding seniority, wages and other gains along with their working period have increased, but they could not find these opportunities within the sector, as a result of which their job satisfaction level decreased. It was stated that there could be a relationship among the results due to the increase in age in line with the increasing working period. The results obtained from the studies do not support the findings of our study. As a result of our research, it has been revealed that the working periods of new and senior sports-sports training specialists in the profession do not affect their job satisfaction levels. 


\section{Ml Macrothink}

A significant difference was determined between the economic status and job satisfaction levels of sports-sports training specialists. It was observed that the average scores of the specialists with bad economic situation were lower compared to other sub-dimensions. In the study conducted by Gholamtoobani (2018), it was stated that there was no relationship between the income status of the participating textile industry employees and their job satisfaction scores, and in the study conducted by Uçucu (2019) for midwives, it was uttered that the income level perceptions of the midwives did not affect their job satisfaction. The research results do not support the results obtained from our study.

Concerning different studies, it was stated in the study conducted by Sina (2019) that the internal, external and general job satisfaction mean scores of those who stated that their monthly income was sufficient were higher than those with insufficient monthly income. In the study of Genkan (2007), it was stated that as the monthly income of physical education teachers increased, their job satisfaction also increased. In this respect, the studies support the results obtained in our research. We can reach the result that the job satisfaction levels of sports-sports training specialists who have a bad economic situation are also low.

As the level of visualizing successful performance by setting targets increases for sports-sports training specialists, it has been observed that self-observation and focusing thoughts on natural rewards and evaluating beliefs and assumptions and self-leadership feelings and thoughts increase at the same rate. It has been observed that there is a highly positive relationship between self-talk and self-leadership situations. It has been observed that there is an increase in the self-leadership feelings and thoughts of the specialists through self-talk in a constructive way. A highly positive relationship was determined between the self-reward thoughts of sports-sports training specialists, the evaluating beliefs and assumptions and their self-leadership conditions. It can be mentioned that self-rewarding specialists distance themselves from negative and dysfunctional ideas and turn to more constructive and effective ideas, and this situation also affects their self-leadership feelings and thoughts at the same time.

We can express that sports-sports training specialists move away from negative and functional ideas through self-observation while evaluating the beliefs and assumptions, they exhibit behaviors that they like more often, and an increase can be in question in their sense of self-leadership in order to achieve individual and organizational success.

It is thought that sports-sports training specialists have more positive thoughts by controlling and observing themselves, and this situation reflects positively on their self-leadership understanding and behaviors and a positive bond is formed between them. It can be specified that self-leadership understanding of the specialists also improve at the same rate as a result of the satisfaction from the behaviors they enjoy doing, and they are successful by motivating themselves better.

In conclusion, it has been discovered that female sports-sports training specialists are more focused on self-talk compared to males this has an effect on their self-leadership levels, but the gender does not affect the job satisfaction levels, the permanent experts motivate themselves for their work better than the contracted experts, and their self-leadership feelings 
are in better condition. It has been observed that the specialists who are new to the profession are in an effort to prove themselves in their institutions and to reveal their self-leadership behaviors more in order to be successful compared to their senior colleagues, but the same situation does not affect the job satisfaction levels of senior or new specialists in the profession, and sports-sports training specialists with poor economic situation have low job satisfaction.

It has been determined that the self-leadership feelings of the experts who motivate themselves through self-talk and visualize successful performance by setting targets are more developed. It has been observed that there is an increase in the self-leadership feelings and thoughts of the specialists through self-talk in a constructive way. It has been seen that self-rewarding specialists distance themselves from negative and dysfunctional ideas and turn to more constructive and effective ideas, and this situation also reflects positively on their self-leadership emotions and behaviors. It has been determined that sports-sports training specialists observe themselves better by moving away from negative and functional ideas while evaluating their thoughts and ideas and there is an increase in their sense of self-leadership in order to achieve individual and organizational success by exhibiting the behaviors that they like more often. It has also been ascertained that sports-sports training specialists have more positive thoughts by controlling themselves and this situation has a positive impact on self-leadership behaviors.

\section{References}

Akkan, Ö. (2008). Job Satisfaction of Teachers Employed at Occupational State Schools (Unpublished Master thesis, Yeditepe University, Istanbul).

Anderson, J. S., \& Prussia, G. E. (1997). The Self-Leadership Questionnaire: Preliminary Assessment of Construct Validity. The Journal of Leadership Studies, 4(2), 119-143. https://doi.org/10.1177/107179199700400212

Arl1, Ö. (2011). Antecedent and Consequences of Self-Leadership: A Study on Primary School Teachers (Master thesis, Turkish Military Academy Defense Science Institute, Department of Defense Management, Ankara).

Aşan, Ö., \& Erenler, E. (2008). Relationship Between Job Sat1sfaction and Life Satisfaction. The Journal of Faculty of Economics and Administrative Sciences, 13(2), 203-216.

Bayrak Kök, S. (2006). Job Sat1ifaction and Organizational Commitment Examination: A Research. The Journal of Faculty of Economics and Administrative Sciences, 2(1), 291-317.

Can, H., Azizoğlu, A. Ö., \& Miski, A. E. (2015). Organizational Behavior. Political Bookstore, Ankara.

Eğinli Temel, A. (2009). Employee Job Satisfaction: Public and Private Sector a Research on the Job Satisfaction of Employees. The Journal of Faculty of Economics and Administrative Sciences, 23(3), 35-52.

Eren, E. (2017). Organizational Behavior and Management Psychology (p. 16). Just as 
Publishing, Beta Publishing and Distribution Inc., Istanbul.

Ergöz, M. (2018). Between Self-Leadership and Organizational Commitment Examinatıon of the Relationship: Research at a State Hospital (Master thesis, Social Sciences Institute, Department of Business Administration, Business Administration, Istanbul Gelisim University, İstanbul).

Gençay, Ö. A. (2007). Examination of Job Satisfaction and Burnout Levels of Physical Educators According to the Some Variables. Kastamonu Journal of Education, 15(2), 765-780.

Gholamtoobani, A. (2018). Job Satisfaction in Textile Sector Employees: Republic of Iran Tehran City an Application (Master thesis, Business Management Program, Institute of Social Sciences, Department of Business Administration, Istanbul Aydın University, Istanbul).

Gürkan, H., Barut, C., Ünsel, O., \& Aybay, E. (2017). Examination of the relationship between Demographic Variables and Job Satisfaction: Implementation of Bitlis Tourism Sector Employees. Bitlis Eren University Institute of Social Sciences Journal, 6(2), 130-157.

Güvel, C. (2019). Personality traits effects on job satisfaction: Example of Adana Seyhan Municipality (Master's thesis, Social Sciences Institute, Çă̆ University).

Houghton, J. D., \& Neck, C. P. (2002). The Revised Self-Leadership Questionnaire: Testing a Hierarchical Factor Structure for Self-Leadership. Journal of Managerial Psychology, 17(8), 672-692. https://doi.org/10.1108/02683940210450484

James, A. M. (2009). Self-leadership and self-regulated learning: An investigation of theoretical relationships. Journal of Business \& Leadership: Research, Practice, and Teaching (2005-2012), 5(1), 59-67.

Karakuş, H. (2011). The Effects of Mobbing on Nurses and Job Satisfaction: The Example of Sivas Province (PhD thesis, Sivas, Turkey).

Karakuzu, M. (2019). Examination of the Job Satisfaction, Colleague Relations, and School Administration Support in Physical Education Teachers (Master thesis, Graduate School of Social Sciences, Aksaray University, Turkey).

Kerr, S., \& Jermier, J. M. (1978). Substitutes for leadership: Their meaning and measurement. Organizational Behavior and Human Performance, 22(3), 375-403.

Manz, C. C. (1986). Self-leadership: Toward an expanded theory of self-influence processes in organizations. Academy of Management Review, 11(3), 585-600.

Manz, C., \& Neck, C. (2004). Mastering self-leadership: Empowering yourself for personal excellence (3rd ed.). Prentice Hall Press.

Mercanlıoğlu, A. Ç. (2012). Differences in the Job Satisfactıon's Dimensions with Respect to the Demographic Factors: A Research. Journal of Suggestion, 10(37), 121-138. https://doi.org/10.5328/cter37.2.121 


\section{Macrothink

Neck, C. P., \& Houghton, J. D. (2006). Two decades of self-leadership theory and research: Past developments, present trends, and future possibilities. Journal of Managerial Psychology, 21(4), 270-295. https://doi.org/10.1108/02683940610663097

Önen, S. M., \& Kanayran, H. G. (2015). Leadership and Motivation: A Theoretical Assessment Individual and Society. Journal of Social Science, 5(2), 43-64. https://doi.org/ $10.20493 / \mathrm{bt} .25754$

Özkalp, E., \& Kırel, Ç. (2016). Organizational Behavior (7th ed.). Ekin Press, Broadcast Distribution, Bursa.

Öztekin, Z. (2008). Job Satisfaction in the Army: Officers on Factors Affecting Job Satisfaction-A Comparative Study ( $\mathrm{PhD}$ thesis, Institute of Social Sciences, Anadolu University, Eskisehir).

Pearce, C. L., \& Manz, C. C. (2005). The new silver bullets of leadership: The importance of self-and shared leadership in knowledge work. Organizational Dynamics, 34(2), 130-140. https://doi.org/10.1016/j.orgdyn.2005.03.003

Sarıbay, E., \& Sarıbay, B. (2016). A Research on the Examination Demographic Variables with Job Satisfaction and Its Relationship with Nonparametric Statistical Methods and Factor Analysis. The Journal of Academic Social Science, 4(30), 580-603. https://doi.org/10.16992/ ASOS.1376

Sina, I. (2019). Healthcare Professionals Evaluation in terms of Motivation and Job Satisfaction: An Application in Three Different Hospitals in Niger ( $\mathrm{PhD}$ thesis, Health Sciences Institute, Department of Health Institutions Management, Ankara University, Ankara).

Şahal, E. (2005). Between Organizational Culture and Job Satisfaction in Academic Organizations Relationship: PhD Research at Mediterranean University on Organizational Culture and Job Satisfaction of Its Staff Perception and Opinions (Master thesis, Institute of Social Sciences, Department of Public Relations and Publicity, Akdeniz University, Antalya).

Tabak, A., Sığrı, Ü., \& Türköz, T. (2013). The Study of Adapting the Self-Leadership Scale to Turkish. Journal of Bilig, 67, 213-246. https://doi.org/10.12995/bilig.2013.6710

Tor, S. S., \& Esengün, K. (2011). The Demographic Factors, in Organizations, That are Effecting the Job Satisfaction and Productivity: One Exercise of a Company in Food Industry in Karaman. Journal of Social and Economic Studies, 13(20), 5363.

Tunacan, S., \& Çetin, C. (2009). A Study on Determination the Factors That Effect State School Teachers' Job Satisfaction. Marmara University Atatürk Faculty of Education Journal of Educational Sciences, 29, 155-172.

Uçucu, G. (2019). Organizational Commitment Job Satisfaction and Factors Affecting the Obstetrics in Aydin Province (PhD thesis, Midwife Program, Health Science Institute, Aydin Adnan Menderes University, Aydın). 
Yavuz, E., \& Ayhan, B. (2019). Determination of Self-Leadership Level in Public Organizations. International Journal of Society Researches, 10(17).

\section{Copyright Disclaimer}

Copyright for this article is retained by the author(s), with first publication rights granted to the journal.

This is an open-access article distributed under the terms and conditions of the Creative Commons Attribution license (http://creativecommons.org/licenses/by/3.0/). 